\title{
Mesin Pengupas Bawang Mudah - Alih (Portable Onion Peeler Machine)
}

\author{
Sahrudin, Dimas Ramadhan Putra, Jhav Sund Octoricoento, Mujirudin, Harry Ramza \\ Program Studi Teknik Elektro, Fakults Teknik. Universitas Muhammadiyah Prof. Dr. HAMKA \\ Jalan Tanah Merdeka No 6, Kp Rambutan, Jakarta, Indonesia \\ Telp : +62-21-8400341, Faks : +62-21-8411531 \\ E-mail : sahrudinace@gmail.com*; dimasramadhanptr@gmail.com; royale.jhavsund@gmail.com \\ mujirudin@uhamka.ac.id; hramza@uhamka.ac.id
}

\begin{abstract}
Abstrak - Proses pengelolahan hasil-hasil pertanian menjadi suatu bahan pangan bagi masyarakat menjadi hal yang menarik untuk diketahui lebih dalam. Salah satunya yaitu pengelolahan bawang yang berkapasitas banyak untuk proses pengupasan. Didalam proses pengolahan bawang terdapat beberapa kendala yang membuat produksinya menjadi menghambat salah satunya yaitu dalam pengupasan kulit bawang merah dan bawang putih dengan cara dirajang untuk mengupasnya. Para produsen sering sekali merasa kesulitan untuk membersihkan kulit bawang pada saat pengupasan, apalagi yang sudah bertaraf besar. Perancangan alat ini dibuat untuk membantu dalam proses pengupasan bawang dalam jumlah banyak yang menggunakan tenaga motor listrik sebagai penggeraknya, Mikrontroler sebagai otak untuk menjalankan proses alat yang dirancang dan sensor berat(load cell) untuk menghitung nilai dari kapasitas berat bawang. Kabel ties tersebut berfungsi sebagai pembantu dalam pengupasan bawang dengan cara membenturkanya. Dengan tujuan Menentukan nilai efesiensi ketebalan kulit kupas dan kapasitas berat dari bawang, sehingga variasi yang paling bagus untuk digunakan adalah variasi kombinasi dengan nilai efesiensi sebesar $17 \%$ untuk ketebalan dan $3 \%$ untuk kapasitas berat bawang.
\end{abstract}

Kata Kunci : Motor Listrik, Mikrokontroler, Sensor Berat(Load cell) dan Kabel Ties

\begin{abstract}
The process of processing agricultural products into a food for the community becomes an interesting thing to know more deeply. One of them is pengelolahan onion with a lot of capacity for stripping process. In the process of onion processing there are several obstacles that make its production to inhibit one of them is in stripping the skin of onion and garlic by means of chopped to peel it. The producers often find it difficult to clean the onion skin at the time of stripping, let alone a large degree. The design of this tool is made to assist in the process of stripping the onion in large quantities using electric motor power as the driving force, the microcontroller as the brain to run the process of designed devices and load sensors to calculate the value of the weight capacity of the onion. The ties cable serves as a helper in stripping onions by banging them. With the aim of Determining the value of the efficiency of the thickness of the peel skin and the weight capacity of the onion, so that the best variation to be used is the variation of the combination with a value of efficiency of $17 \%$ for thickness and 3\% for the weight capacity of the onion.
\end{abstract}

Keywords: Electric Motor, Microcontroller, Sensor Weight (Load cell) and Cable Ties

\section{Pendahuluan}

Proses pengelolahan hasil-hasil pertanian menjadi suatu bahan pangan bagi masyarakat menjadi hal yang menarik untuk diketahui lebih dalam. Salah satunya yaitu pengelolahan bawang yang berkapasitas banyak untuk proses pengupasan. Didalam proses pengolahan bawang terdapat beberapa kendala yang membuat produksinya menjadi menghambat salah satunya yaitu dalam pengupasan kulit bawang merah dan bawang putih dengan cara dirajang untuk mengupasnya. para produsen sering sekali merasa kesulitan untuk membersihkan kulit bawang pada saat pengupasan, apalagi yang sudah bertaraf besar. Hal itu tidak bisa dipungkiri karena bawang mengandung zat yang bisa membuat mata merah atau pedas, disamping membutuhkan waktu ekstra untuk mengupasnya. Hal ini menimbulkan banyak ide dalam pengolahan bawang terutama dalam pengupasannya. Salah satu teknologi yang dapat mengatasinya adalah mesin pengupas bawang menggunakan tenaga motor listrik[1]. 
Alat ini di rancang untuk membantu dalam proses pengupasan bawang dalam jumlah banyak yang menggunakan tenaga motor sebagai penggeraknya. Metode yang digunakan adalah dengan cara merotasikan bawang dengan jumlah bertaraf besar yang digunakan diatas toples berlubang dengan kecepatan sudut tertentu. Saat berotasi atau berputar bawang akan membenturkan ke sebuah kabel ties yang telah disusun pada sebuah sumpit, sehingga proses pengupasan terjadi saat bawang tergores dengan kabel ties tersebut. Kabel ties tersebut berfungsi sebagai pembantu dalam pengupasan dengan cara membenturkanya.

\section{Dasar Teori}

\subsection{Pengertian Pengupasan}

Pengupasan merupakan pra-proses dalam pengolahan bahan pangan yang siap untuk dikonsumsi. Pengupasan memiliki tujuan yang sangat penting, yaitu untuk menghilangkan kulit atau penutup luar buah atau sayur. Hal ini dilakukan untuk mengurangi dan meminimalisir terjadinya kontaminasi dan memperbaiki penampakan. Pengupasan dikatakan efisien jika kehilangan komoditas yang dikehendaki kecil.

Pembuangan kulit harus dilakukan dengan cermat agar daging buah tidak ikut terbuang karena hal tersebut dapat mengakibatkan berkurangnya rendemen yang dihasilkan. Tujuan pengupasan ialah untuk membuang bagian-bagian luar yang tidak dimakan dan tidak diinginkan, seperti kulit, tangkai, bagian-bagian yang cacat atau busuk.

\subsection{Teknik Pengupasan}

Pengupasan merupakan suatu proses dalam pengolahan agar didapatkan bahan pangan yang siap untuk dikonsumsi. Pengupasan memiliki tujuan yang sangat penting, yaitu untuk menghilangkan kulit atau penutup luar buah atau sayur. Hal ini dilakukan untuk mengurangi dan meminimalisir terjadinya kontaminasi dan memperbaiki penampakan. Pengupasan dikatakan efisien jika kulit terkupas dengan bersih . Pembuangan kulit harus dilakukan dengan cermat agar daging buah tidak ikut terbuang karena hal tersebut akan mengakibatkan berkurangnya rendemen yang dihasilkan[2].

\subsubsection{Hand Peeling}

Pengupasan dengan tangan umumnya dilakukan dengan menggunakan pisau biasa atau stainless steel. Namun untuk mendapatkan hasil akhir yang baik sebaiknya menggunakan pisau yang berbahan stainless steel jika akan mengupas bahan pangan seperti buah-buahan agar tidak terjadi pewarnaan gelap yang dapat mempengaruhi kenampakan produk. Efisiensi pengupasan rendah dan lebih efektif untuk mengupas bahan yang berukuran besar[3].

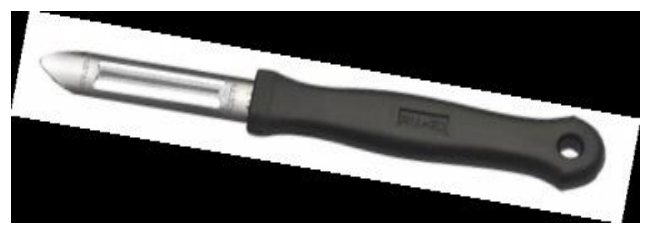

Gambar Error! No text of specified style in document..1 Hand Peeling

\subsubsection{Rotate Peeler}

Rotate Peeler adalah pengupas kulit bawang yang menggunakan pisau sebagai alat pengupasnya. Alat ini mempunyai tuas pemutar yang berfungsi sebagai penggerak dan terdapat dua penjepit yang dapat di atur posisinya. Bagian bawah pemutar bawang dan bagian atas penjepit yang berbentuk jarum, seperti yang ditunjukan pada Gambar 2.2. Prinsip kerja alat ini yaitu jika tuas diputar searah dengan arah jarum jam, maka penjepit bawah memutar bawang dan pisau mulai mengupas dari bagian atas hingga bagian bawah bawang. Pisau pengupas bergerak secara otomatis dari atas kebawah mengikuti alur ulir

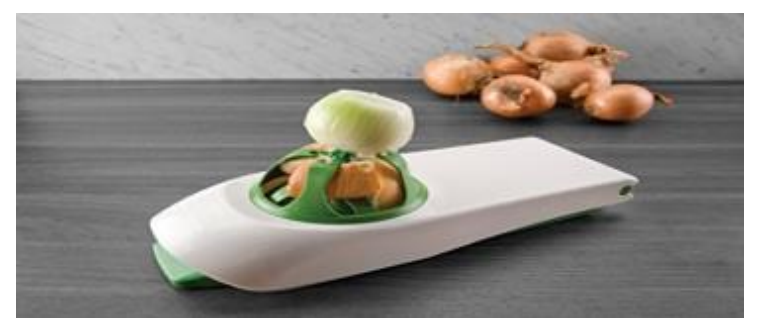

Gambar Error! No text of specified style in document. 2 Rotate Peeler

\subsubsection{Electric Peeler}

Electric peeler merupakan pengupas kulit bawang yang menggunakan sistem elektrik. Alat ini mempunyai kapasitas $1,5 \mathrm{~kg}$ dalam satu proses pengupasan. Pisau pengupas electric peeler menggunakan metode pengupasan menggunakan permukaan kasar. Prinsip kerja alat ini yaitu piringan yang digerakan oleh motor, berputar mendorong kentang sehingga terjadi gesekan antara bawang dan permukaan kasar, gesekan-gesekan ini yang menyebabkan terkelupasnya kulit bawang, bentuk mesin electric peeler dapat dilihat pada Gambar 2.3

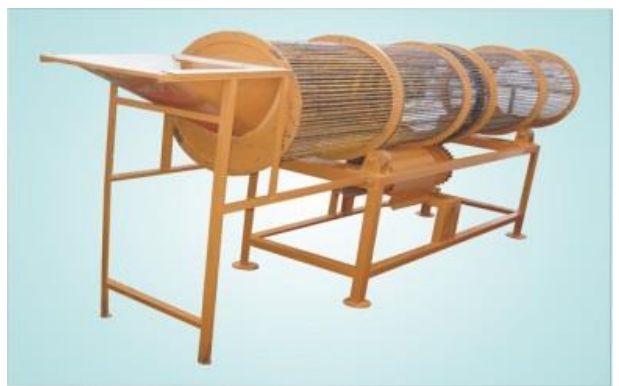

Gambar Error! No text of specified style in document..3 Electric Peeler

\subsubsection{Machine Peeling}

Pengupasan dengan mesin, pengupasan secara mekanis berdasarkan abrasi terutama pada bawang, kentang, umbiumbian, wortel dan lain-lain. Alat ini dapat bekerja secara kontinyu dan batch. Alat pengupas ini terdiri dari suatu lempengan yang permukaannya kasar yang berputar dan bersinggungan langsung dengan permukaan bahan sehingga kulit terkupas. Adanya gesekan antara bahan dengan permukaan kasar akan menyebabkan mengelupasnya kulit buah. Untuk buah dengan bentuk yang tidak beraturan, maka akan dihasilkan limbah dalam jumlah yang lebih besar, tetapi 
keuntungannya proses pengupasan menjadi relatif lebih cepat.

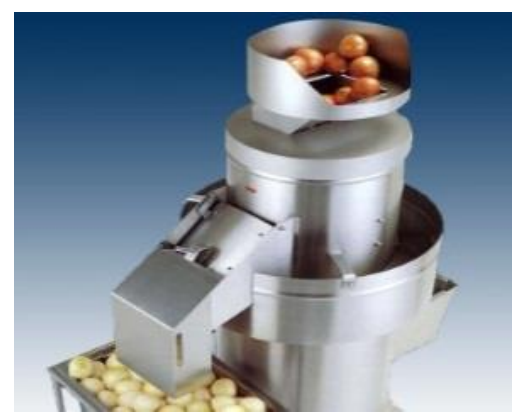

Gambar Error! No text of specified style in document. 4 Machine Peeling

\subsection{Motor Listrik AC}

Jenis motor listrik yang bekerja menggunakan tegangan AC (Alternating Current). Motor AC memiliki dua buah bagian utama yaitu stator dan rotor. Stator merupakan komponen motor AC yang statis. Rotor merupakan komponen motor AC yang berputar. Motor AC dapat dilengkapi dengan penggerak frekuensi variabel untuk mengendalikan kecepatan sekaligus menurunkan konsumsi dayanya[4].

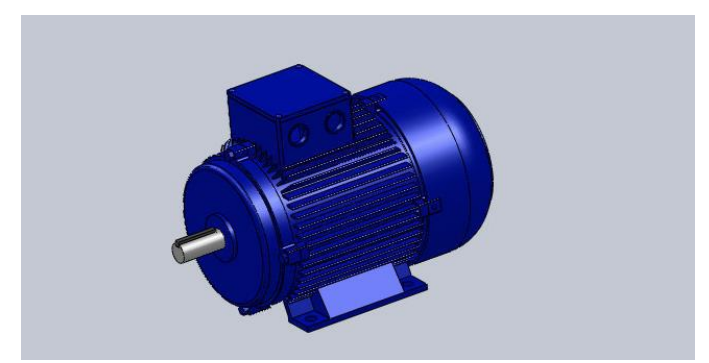

Gambar Error! No text of specified style in document. .5 Skema Motor Listrik AC

\subsection{Mikrokontroler}

Mikrokontroler merupakan komputer didalam chip yang digunakan untuk mengontrol peralatan elektronik, yang menekankan efisiensi dan efektifitas biaya. Secara harfiahnya bisa disebut pengendali kecil dimana sebuah sistem elektronik yang sebelumnya banyak memerlukan komponen-komponen pendukung seperti IC TTL dan CMOS dapat direduksi/diperkecil dan akhirnya terpusat serta dikendalikan oleh mikrokontroler ini. Agar sebuah mikrokontroler dapat berfungsi, maka mikrokontroler tersebut memerlukan komponen eksternal yang kemudian disebut dengan sistem minimum. Untuk membuat sistem minimal paling tidak dibutuhkan sistem clock dan reset, walaupun pada beberapa mikrokontroler sudah menyediakan sistem clock internal, sehingga tanpa rangkaian eksternal pun mikrokontroler sudah beroperasi. Yang dimaksud dengan sistem minimal adalah sebuah rangkaian mikrokontroler yang sudah dapat digunakan untuk menjalankan sebuah aplikasi. Sebuah IC mikrokontroler tidakakan berarti bila hanya berdiri sendiri. Pada dasarnya sebuah sistem minimal mikrokontroler AVR memiliki prinsip yang sama[5].

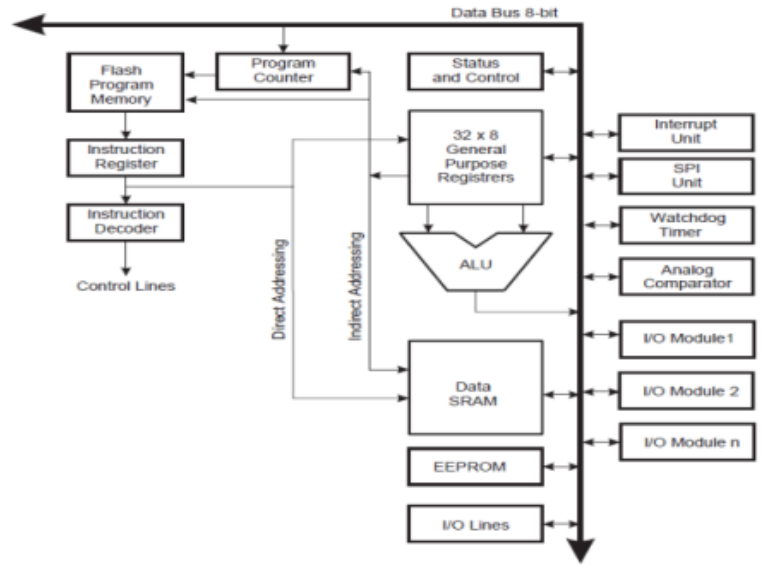

Gambar 2.6 Skema AVR ATMega328

\subsection{LCD(Liquid Cristal Display)}

Display elektronik adalah salah satu komponen elektronika yang berfungsi sebagai tampilan suatu data, baik karakter, huruf ataupun grafik. LCD (Liquid Cristal Display) adalah salah satu jenis display elektronik yang dibuat dengan teknologi CMOS logic yang bekerja dengan tidak menghasilkan cahaya tetapi memantulkan cahaya yang ada di sekelilingnya terhadap front-lit atau mentransmisikan cahaya dari back-lit. LCD (Liquid Cristal Display) berfungsi sebagai penampil data baik dalam bentuk karakter, huruf, angka ataupun grafik. LCD adalah lapisan dari campuran organik antara lapisan kaca bening dengan elektroda transparan indium oksida dalam bentuk tampilan sevensegment dan lapisan elektroda pada kaca belakang. Ketika elektroda diaktifkan dengan medan listrik (tegangan), molekul organik yang panjang dan silindris menyesuaikan diri dengan elektroda dari segmen[6].

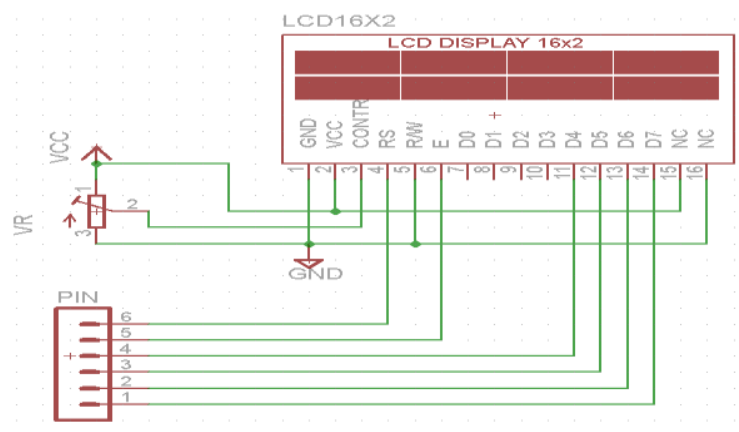

2.7 Skema Lcd (Liquid Crystal Display)

\subsection{Buzzer}

Buzzer adalah sebuah komponen elektronika yang berfungsi untuk mengubah getaran listrik menjadi getaran suara. Pada dasarnya prinsip kerja buzzer hamper sama dengan loudspeaker, jadi buzzer juga terdiri dari kumparan yang terpasang pada diafragma dan kemudian kumparan tersebut dialiri arus sehingga menjadi elektromagnet, kumparan tadi akan tertarik ke dalam atau keluar, tergantung dari arah arus dan polaritas magnetnya, karena kumparan dipasang pada 
diafragma maka setiap gerakan kumparan akan menggerakan diafragma secara bolak-balik sehingga membuat udara bergetar yang akan menghasilkan suara. Buzzer biasanya digunakan sebagai indikator bahwa proses telah selesai atau terjadi suatu kesalahan pada sebuah alat (alarm)[7].

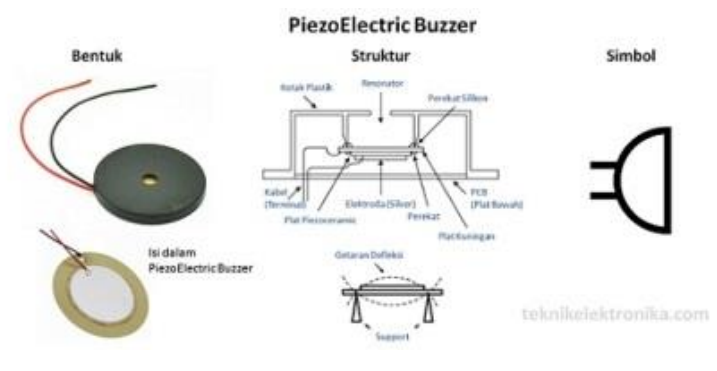

Gamar 2.8 Skema Fisik Buzzer

\subsection{Sensor Berat(LoadCell)}

Sensor load cell adalah sensor yang digunakan untuk mengukur berat atau beban dari suatu benda dalam ukuran besar. Sensor strain gauge ini sering diaplikasikan pada jembatan timbangan mobil atau alat ukur berat dalam skala besar. Sensor load cell adalah grid metal-foil yang tipis yang diletakan pada permukaan dari struktur. Apabila komponen atau struktur dibebani, akan terjadi strain dan ditransmisikan ke foil grid. Tahanan foil grid berubah sebanding dengan induksi beban, Sensor strain gauge pada umumnya adalah tipe metal-foil, dimana konfigurasi grid dibentuk oleh proses photoeching sederhana, maka dapat dibuat bermacam macam ukuran gauge dan bentuk grid [8].

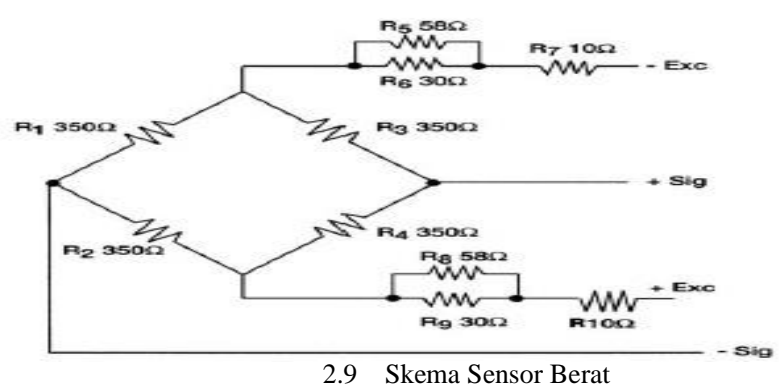

\section{Metodologi Penelitian}

3.1 Rangkaian Power Supply(Catu Daya)

Dalam perancangan ini penulis menggunakan rangkaian power supply yang bertujuan untuk menyuplai tegangan atau arus listrik secara langsung ke perancangan sistem yang dibuat untuk penlitian, yang dimana power supply ini mengubah tegangan $\mathrm{AC}(220$ Volt $)$ menjadi tegangan DC(5 Volt) pada penelitian ini penulis menggunakan tegangan 5 volt DC dikarenakan komponen yang digunakan pada saat perancangan hanya memiliki spesifikasi tegangan 5 volt DC, jika melebihi dari 5 Volt maka akan terjadi kerusakan pada komponen tersebut sehingga perancangan sistem yang tidak dapat dioperasikan

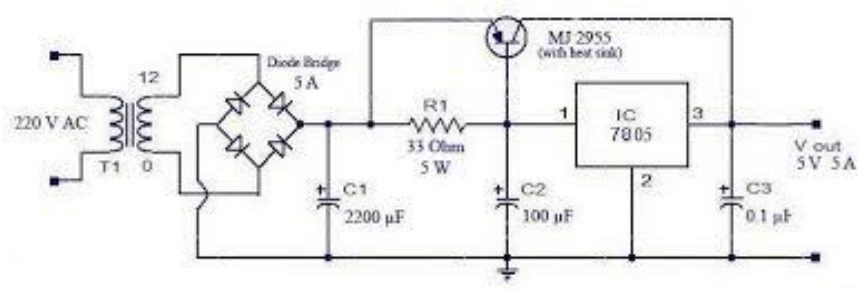

Gambar 3.1 Skematik Rangkaian Power Supply

\subsection{Rangkaian Lcd (Liquid Crystal Display)}

Dalam perancangan ini penulis menggunakan LCD 16x2 sebagai alat pendukung yang digunakan untuk perancangan sistem dikarenakan LCD 16x2 ini memiliki 16 kolom dan 2 baris teks, sehingga cukup untuk menuliskan sebuah teks yang akan buat untuk perancangan sistem. Rangkaian LCD (Liquid Crystal Display) ini berfungsi untuk menampilkan teks berupa berat kapasitas bawang yang dikirimkan melalui sensor berat (load cell).

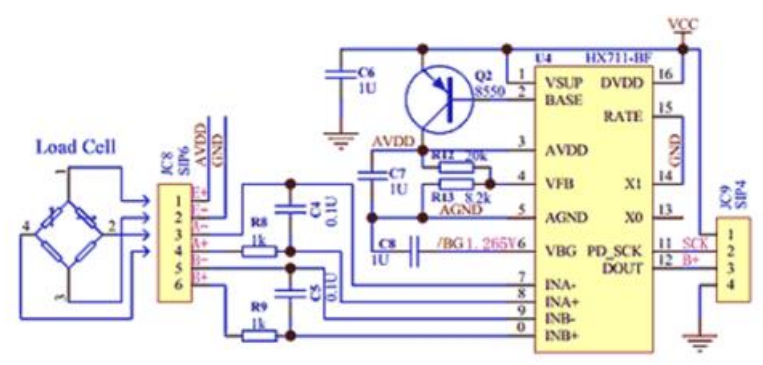

Gambar 3.2 Skematik Rangkaian LCD 16x2

\subsection{Rangakain Buzzer}

Dalam perancangan ini penulis menggunakan Buzzer dalam perancangan sistem yang berfungsi untuk mengaktifkan buzzer sebagai tanda bahwa berat kapasitas bawang tersebut melebihi kapasitas yang digunakan pada saat pengupasan bawang. Buzzer yang digunakan penulis pada perancangan ini menggunakan buzzer dengan tegangan 5 Volt DC dikarenakan suara yang dihasilkan oleh buzzer tidak terlalu keras pada saat buzzer aktif. Rangkaian buzzer yang dihubungkan ke mikrokontroler mendapat perintah high $(5 \mathrm{~V})$ jika terdapat tegangan dan akan low (0V) jika tidak terdapat tegangan.

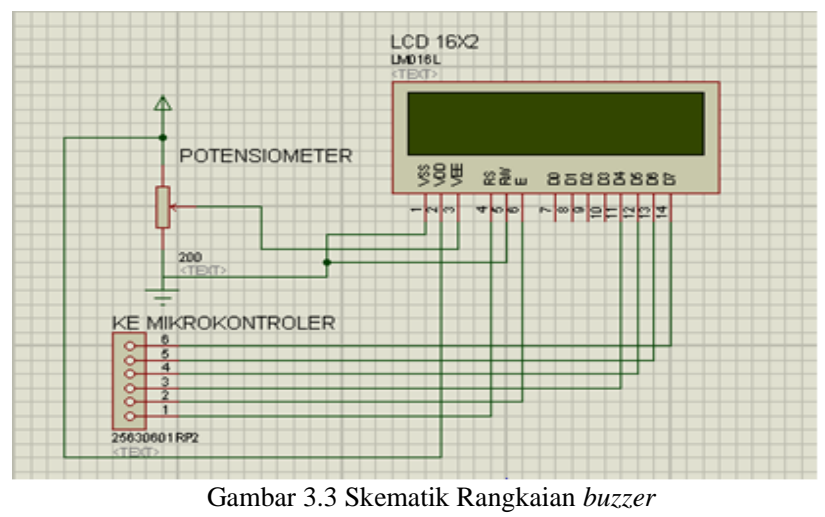

Seminar Nasional TEKNOKA ke - 3, Vol. 3, 2018 ISSN No. 2502-8782 


\subsection{Rangkaian Sensor Berat (Load Cell)}

Dalam perancangan ini penulis menggunakan sensor berat(load cell) yang berfungsi untuk membaca nilai pada suatu berat yang akan ditimbang, dikarenakan sensor berat(load cell) ini menyuplai tegangan kurang dari 10Volt sehingga pada saat sensor ini aktif maka sangat sensitif pada saat menjalankankanya. Rangkaian sensor berat (load cell) ini sebagai pengolah utama dari data yang diterima oleh mikrokontroler.

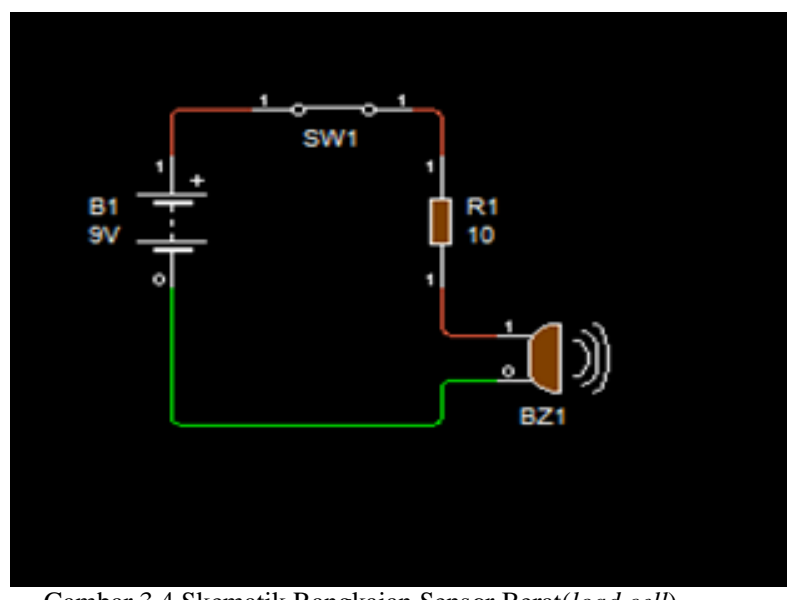

Gambar 3.4 Skematik Rangkaian Sensor Berat(load cell)

\subsection{Rangkaian Relay}

Dalam perancangan ini penulis menggunakan relay dengan tegangan 5VDC dengan ampere 10A dikarenakan penulis menggunakan relay tersebut mampu menggerakan armature relay yang berfungsi sebagai saklarnya untuk menghantar listrik dengan tegangan 220VAC. Rangkaian Relay ini berfungsi untuk mengaktifkan/menghidupkan relay dengan istilah lain rangkaian ini disebut driver relay, pada rangkaian ini terdapat transistor 2n3904 jenis NPN yang berfungsi sebagai saklar otomatis saat pin dari rangkaian relay yang ke mikrokontroler mendapat perintah high $(5 \mathrm{~V})$ yang masuk kekaki base pada transistor, maka transistor aktif dan relay juga aktif.

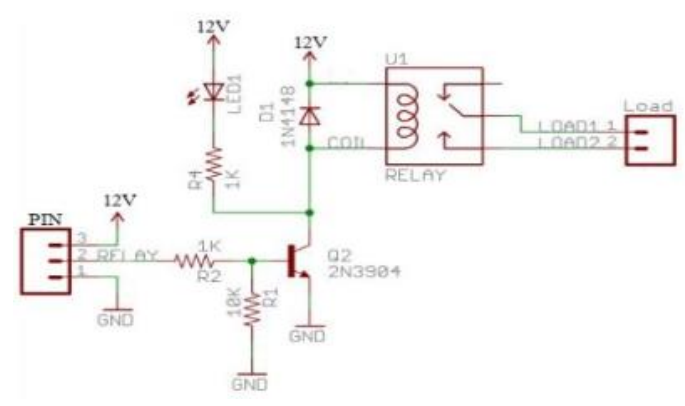

Gambar 3.5 Skematik Rangkaian Relay

3.6 Rangkaian Keseluruhan Mesin Pengupas Bawang Perancangan alat pengupas elektrik bawang dibuat dengan skematik seperti gambar 3.12 diatas, dengan tegangan sumber $5 \mathrm{~V}-9 \mathrm{~V}$ dan menggunakan ic 328 sebagai pengontrol dari semua komponen tersebut. Rangkaian tersebut menggunakan sensor untuk mendeteksi sebuah beban yang akan digunakan, lcd menampilkan sebuah teks berupa tulisan dan angka dengan memberikan teganagan 5V, komponen potensiometer berfungsi untuk memnrikan kecerahan pada layar lcd.

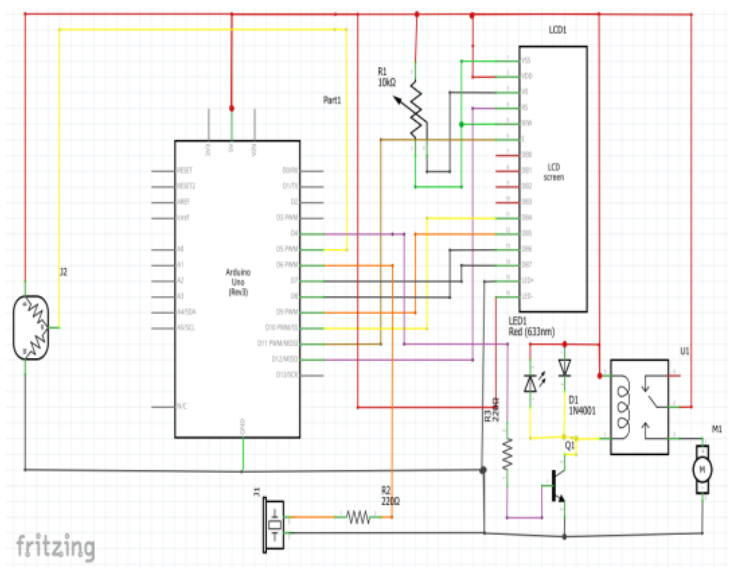

Gambar 3.6 Skematik Rangkaian Mesin Pengupas Bawang

\subsection{Spesifikasai Motor Listrik AC}

Pada setiap motor baik itu motor AC, motor DC, motor servo, motor listrik terdapat spesifikasi dari motor itu sendiri yaitu berupa kecepatam motor, torsi (barat beban), tegangan masukan, arus, dan efisiensi daya. Berikut spesifikasi tabel motor listrik AC yang digunakan oleh penulis:

Tabel Error! No text of specified style in document.. 1 Spesifikasi Motor Listrik AC

\begin{tabular}{ll}
\hline Kecepatan Motor & $6000 \mathrm{rpm}$ \\
Tegangan Masukan & 220 Volt \\
Daya Motor & $100 \mathrm{Watt}$ \\
Arus Listrik & $0,5 \mathrm{~A}$ \\
Frekuensi & $59 \mathrm{HZ}$ \\
\hline
\end{tabular}

Berikut ini adalah rumus untuk mencari efisiensi pada daya motor dapat dilihat pada persamaan 1 :

$$
\begin{array}{r}
n=\frac{\mathrm{P} \text { out }}{\mathrm{P} \text { in }} \times 100 \% \\
n=\frac{100 \mathrm{Watt}}{220 \text { Volt }} \times 100 \%
\end{array}
$$

\section{5,454\% Efisiensi Daya Motor}

$$
\begin{array}{ll}
\text { Dimana: } & \\
\mathrm{n} & =\text { Efisiensi daya motor } \\
\mathrm{P} \text { outout } & =\text { Daya ouput } \\
\mathrm{P} \text { in } & =\text { Input daya }
\end{array}
$$

Jadi efisiensi untuk daya motor listrik AC adalah $45,454 \%$

Berikut rumus untuk menghitung torsi motor jika diketahui daya motor dan kecepatan motor persamaan 2 .

$$
T=\frac{5250 . \mathrm{HP}}{\mathrm{n}}
$$


Dimana :

$$
T=\frac{5250.100}{6000}=87,5 \mathrm{Nm}
$$

$\mathrm{T} \quad=$ Torsi motor (dalam $\mathrm{lb} \mathrm{ft}$ )

$\mathrm{n} \quad=$ Kecepatan putar motor

$\mathrm{HP}=$ Daya kuda motor

$5250=$ Konstan

Jadi Torsi untuk motor listrik AC adalah $87,5 \mathrm{Nm}$ (newton meter)

\subsection{Desain Sistem}

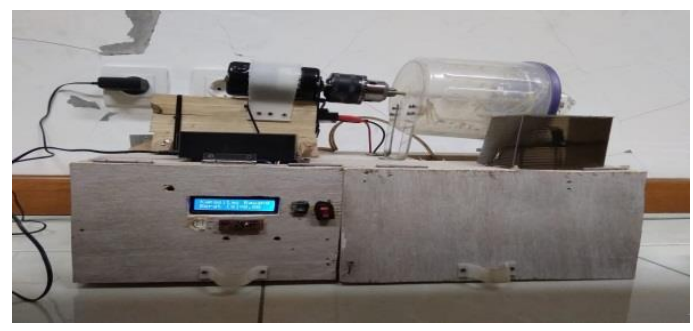

Gambar 3.7 Desain Sistem

Gambar 3.7 diatas merupakan perancangan yang akan dibuat untuk alat pengupas elektrik bawang yang meliputi beberapa komponen dan kegunaan dari setiap -setiap komponen yang meliputi :

1. Arduino : untuk mengontrol dari semua alat pengupas elektrik bawang

2. Buzzer : berfungsi untuk memberikan sebuah tanda(bunyi) untuk mengetahui proses dari alat tersebut

3. Lcd : untuk menampilkan sebuah teks berupa tulisan huruf sebagai pemberitahuan bahwa alat tersebut dapat diproses

4. Sensor berat : berfungsi untuk memberikan kapasitas berat dari suatu objek yang akan digunakan

5. Dinamo : berfungsi untuk menjalankan suatu alat pengupas elektrik bawang

6. Toples : berfungsi untuk menempatkan bawang didalam wadah(toples)

7. Kabel ties : berfungsi untuk pengupasan pada kulit bawang

\subsection{Program Sistem}

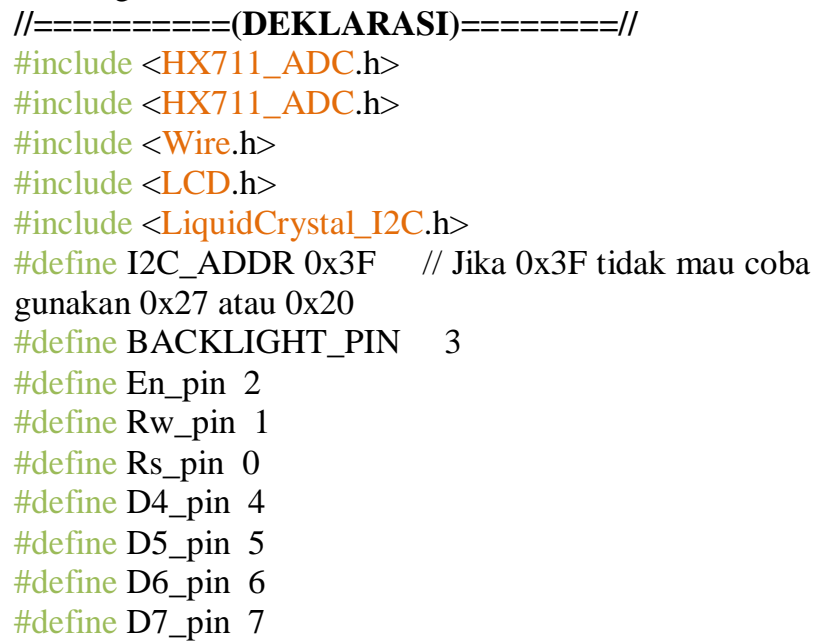

LiquidCrystal_I2C

lcd(I2C_ADDR,En_pin,Rw_pin,Rs_pin,D4_pin,D5_pi n,D6_pin,D7_pin);//Ubah alamat 0x3F

HX711_ADC LoadCell $(4,5)$;

const int pinAlarm $=6$;

const int buttonPin $=8$;

const int motordc $=10$;

int data;

int buttonState $=0$;

\section{$/ /=========($ VOID SETUP $=======/ /$ \\ void $\operatorname{setup}()\{$ \\ pinMode(pinAlarm, OUTPUT); \\ pinMode(motordc, OUTPUT); \\ pinMode(buttonPin, INPUT);}

LoadCell.begin(); // start connection to HX711

LoadCell.start(2000); // load cells gets $2000 \mathrm{~ms}$ of time to stabilize

LoadCell.setCalFactor(2000.0); // calibration factor for load cell $=>$ strongly dependent on your individual setup

lcd.begin(16, 2); // begins connection to the LCD module

lcd.backlight();

lcd.begin $(16,2)$

lcd.setBacklightPin(BACKLIGHT_PIN,POSITIVE); lcd.setBacklight(HIGH);

\}

\section{$/ /=========($ VOID LOOP $)=====/ /$}

void loop()\{

LoadCell.update(); // retrieves data from the load cell

float $\mathrm{i}=$ LoadCell.getData(); // get output value

if $(\mathrm{i}<=10)\{$

$\mathrm{i}=0$;

\}

lcd.setCursor(0, 0);//baris pertama

lcd.print("Kapasitas Bawang:"); // menampilkan teks

lcd.setCursor $(0,1)$; //baris kedua

lcd.print("Berat [g]=");// menampilkan teks

lcd.print(i);

int buttonState $=$ digitalRead(buttonPin);

if $(\mathrm{i}>=130) / /$ alarm hidup

\{

digitalWrite(pinAlarm, HIGH);

delay (500);

digitalWrite(pinAlarm, LOW);

delay(500);

if $(\mathrm{i}<=130) / /$ motor dc hidup

digitalWrite(motordc, HIGH);

delay(10);

digitalWrite(motordc, LOW);

delay(100);

\}

else 
\{

digitalWrite(pinAlarm, LOW);//alarm mati

digitalWrite(motordc, HIGH);// motor dc mati \}

\}

3.10 Flowchart Sistem Kerja

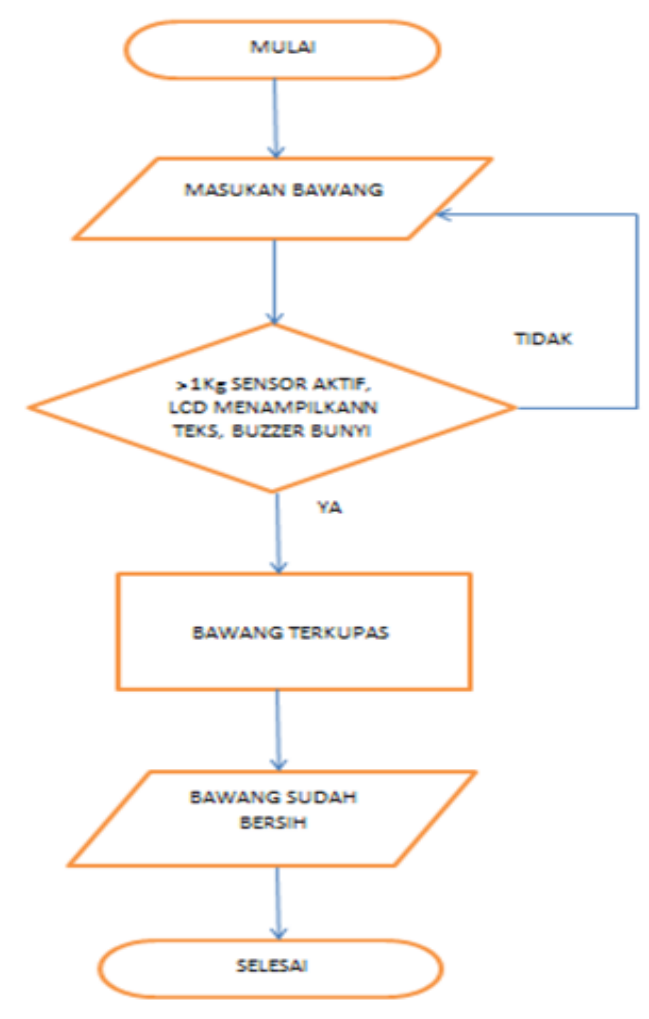

3.8 Diagram Alir

\section{Simpulan}

Berdasarkan penelitian yang telah dilakukan oleh penulis tentang perancangan alat pengupas elektrik bawang, maka dapat dihasil kesimpulan sebagai berikut :

1. Hasil yang diperoleh dengan sudut $90^{\circ}$ dengan ketebalan kulit kupas bawang yang paling bagus digunakan adalah variasi Bersilang dan variasi Tunggal dengan nilai efesiensi sebesar $30 \%$ dan $115 \%$. Sedangkan Hasil yang diperoleh dengan sudut $180^{\circ}$ dengan ketebalan kulit kupas bawang yang paling bagus digunakan adalah variasi Bersilang dan variasi Kombinasi dengan nilai efesiensi sebesar $17 \%$ dan $50 \%$.

2. Hasil yang diperoleh dengan sudut $90^{\circ}$ dengan kapasitas berat bawang yang paling bagus digunakan adalah variasi
Kombinasi dan variasi Bersilang dengan nilai efesiensi sebesar 3\% dan 4\%. Sedangkan Hasil yang diperoleh dengan sudut $180^{\circ}$ dengan kapasitas berat bawang yang paling bagus digunakan adalah variasi Kombinasi dengan nilai efesiensi sebesar 3\% dan $4 \%$.

\section{Penghargaan}

Dalam melakukan penelitian kami turut berterima kasih kepada bapak M.Mujirudin dan bapak Harry Ramza yang telah memberikan saran dan masukan maupun kritik kepada kami dalam melakukan penelitian ini dan juga kepada Dimas Ramadham Putra dan Jhavsund Oktoricoento yang telah membantu dalam penelitian ini dan juga kepada seluruh Fakultas Teknik Elektro UHAMKA dalam melakukan penelitian ini

\section{Kepustakaan}

[1] Wahyu deka sidik, 2017,Rancang Bangun Mesin Pengupas Bawang(bagian poros), Fakultas Teknik Mesin Universitas sebelas maret. Surakarta

[2] Hartono Baswarsiati. E, Karlina., Abu, dan T. Siniati, 2014. Teknologi bawang merah berbasis Good Agriculture practices Direktorat Jendral Holtkultura, Departemen Pertanian.

[3] Darmawan .H, 2016, Pengatar Perancangan Teknik, Direktorat Jendral Pendidikan Tinggi; Jakarta.

[4] Tartono,2015, Perancangan Mesin Pengupas Kulit Kentang Kapasitas $3 \mathrm{Kg} /$ Proses. Yogyakarta

[ 5 ] Badaruddin, 2015,Prinsip Dasar Kerja Motor Listrik. Jakarta

[6] (http://www.learnengineering.org), Single Phase Induction Motor diakses tanggal 2013

[ 7 ] (http://www.insinyoer.com) , Prinsip Kerja Motor Induksi 1 Fasa diakses tanggal 2015

[ 8 ] Atmel Atmega640/V-1280/V-1281/V-2561/V[DATA SHEET]. (2014). Blok Diagram AVR Architecture, USA: 1600 Tecnology Driver,San Jose

[9] Arduino Datasheet, Atmel Corporation,2015.

[ 10 ] Anonim,2010,KarakteristikLCD,http://digilib.petra.ac.id diakses tanggal 10 Juni 2010

[11] Indraharja.(2012) Pengertian Buzzer http://indraharja.wordpress.com 2012/01/07/pengertian-buzzer/. diakses 20 Juli 2017.

[12] Sensor berat load cell www.ricelake.com Load Cell and Weight(AmericaModule $\mathrm{H}: 2010$ )

[13] Darmawan .H, 2016, Pengatar Perancangan Teknik, Direktorat Jendral Pendidikan Tinggi; Jakarta.

[14] Budiharto, Widodo, "Panduan Lenkap Belajar Mikrokontroler dan Aplikasi Mikrokontroler", PT Elex Media Komputindo,2016.

[ 15 ] Andrasto Tatyantoro, Pemantauan Temperatur dan Kelembaban Pada Rumah Kaca Berbasis Mikrokontroler Arduino dan prototype pengiris bawang, Jurnal Teknik Elektro Vol.3 No.2,2015

[16] Muhammad Randi ,Samadi, budi dan Cahyono Bambang, 2015, Bawang Merah Intensifikasi UsahaTani. Yogyakarta : Kanisius 